\title{
Use of prestressed concrete cylinder pipes as composite breakwaters: implementation criterion
}

\author{
A. M. Ghazali \& S. H. Awedat \\ Department of Civil Engineering, Al Fateh University, Tripoli, Libya
}

\begin{abstract}
A conceptual implementation of the use of prestressed concrete cylinder pipes (PCCP) as composite breakwaters for small ports is outlined in this paper. These pipes are of $4 \mathrm{~m}$ diameter and 7.5 meter long while weighing 73.0 metric tons and are produced by the Great Man Made River Project (GMRP) in Libya for water conveyance. The idea is to utilize such pipes in vertical alignment with a submerged rubble mound base so that they behave as composite breakwater. In order to confirm analytical stability computations for such composite breakwater, a two-dimensional physical test model was performed for various water depth and wave action conditions. Test measurements included significant and maximum wave heights, and average and peak wave periods. Model tests were documented by visualization before, during and after all test runs. Stability of the composite breakwater were determined for non-breaking wave conditions, furthermore the design criteria for this use of Prestressed Concrete Cylinder Pipes as composite breakwater is outlined.
\end{abstract}

Keywords: prestressed concrete cylinder pipes, composite breakwater, nonbreaking waves, pipe sliding, pipe overturning, design criteria.

\section{Introduction}

One of the largest civil engineering projects in the world is being executed to deliver water at a rate of about 6 million $\mathrm{m}^{3}$ per day from the south to the coastal North part of Libya and it is called the Great Man-Made River Project (GMRP). The prestressed concrete pipes utilized for this project are of massive sizes, where nonstandard and non-proven technologies have been used in the manufacturing process. This reality coupled with the stringent quality control 
requirement by the GMRP led to the rejection of a large number of these pipes from the use for water conveyance under high internal pressures. Accumulation of such rejected pipes has raised the idea of utilizing them in different usages and for different functions. The ideas of using such pipes as composite breakwaters have attracted the attention of the authors to suggest such usage to the maritime bodies in the country.

The 4-m diameter pipe consists of a welded steel cylinder of $1.9 \mathrm{~mm}$ thickness having a spigot and bell at its ends as shown in Figure 1. After testing the cylinder hydraulically, concrete is cast around it in a vertical position from inside with thickness of $77 \mathrm{~mm}$ and from outside with thickness of $171 \mathrm{~mm}$. Having steam cured, the pipe is transferred for a prestressing process by winding a prestressing cable on the outside diameter in a helical form starting from one end and progressing continuously to the other end. The prestressing force and the pitch between loops depend on the required internal hydraulic pressures.

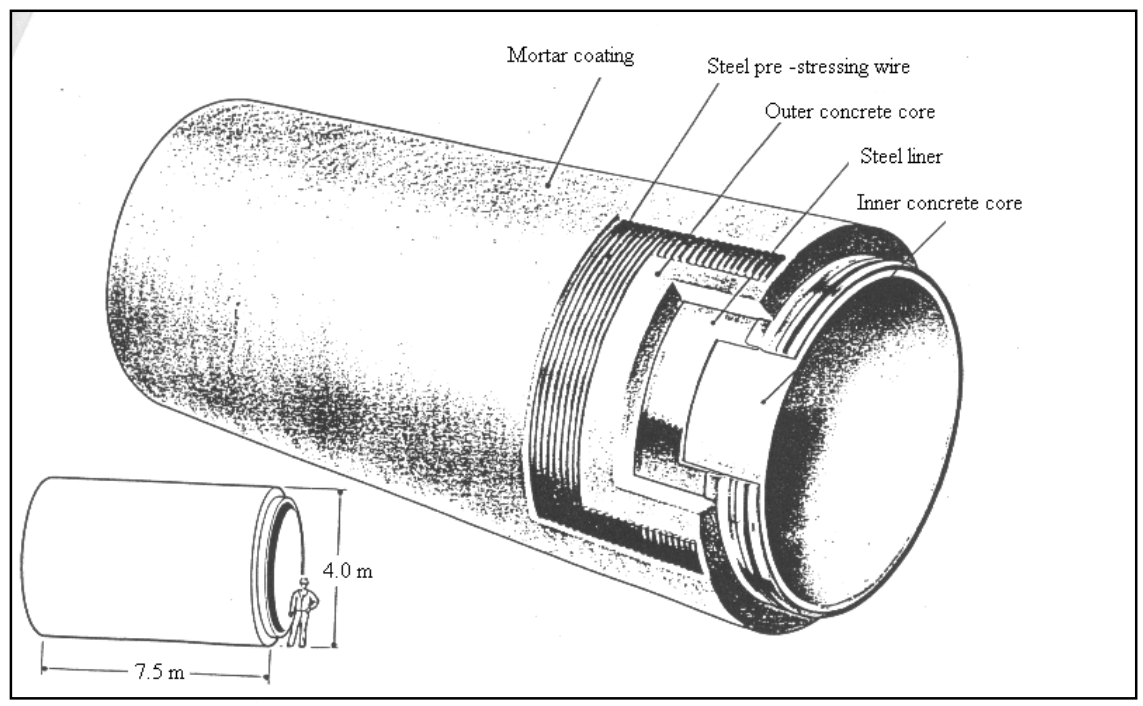

Figure 1: $\quad$ Section through PCCP.

\section{Conceptual Use of the PCCP as Breakwaters}

Vertically aligned 4-m diameter pipes are considered as continuous wall superimposed on a rubble mound base to form a composite breakwater. As shown in Figure 2, the 4-m diameter pipes are aligned vertically with either hook-up joint at the top or a concrete fill of the gap between the pipes over the entire water depth. In both cases the pipes will be filled with rocks (1-60 kg) in weight and capped with a concrete cover slab resulting in, approximately, a selfweight of 250 tons for each pipe. 


\section{Physical hydraulic model}

In order to investigate the behavior of the concept of this composite breakwater, a physical two dimensional model was performed. The main objective of this exercise was to observe stability behavior of the composite structure under sets of wave and water depth conditions and correlate that to analytical stability calculations.

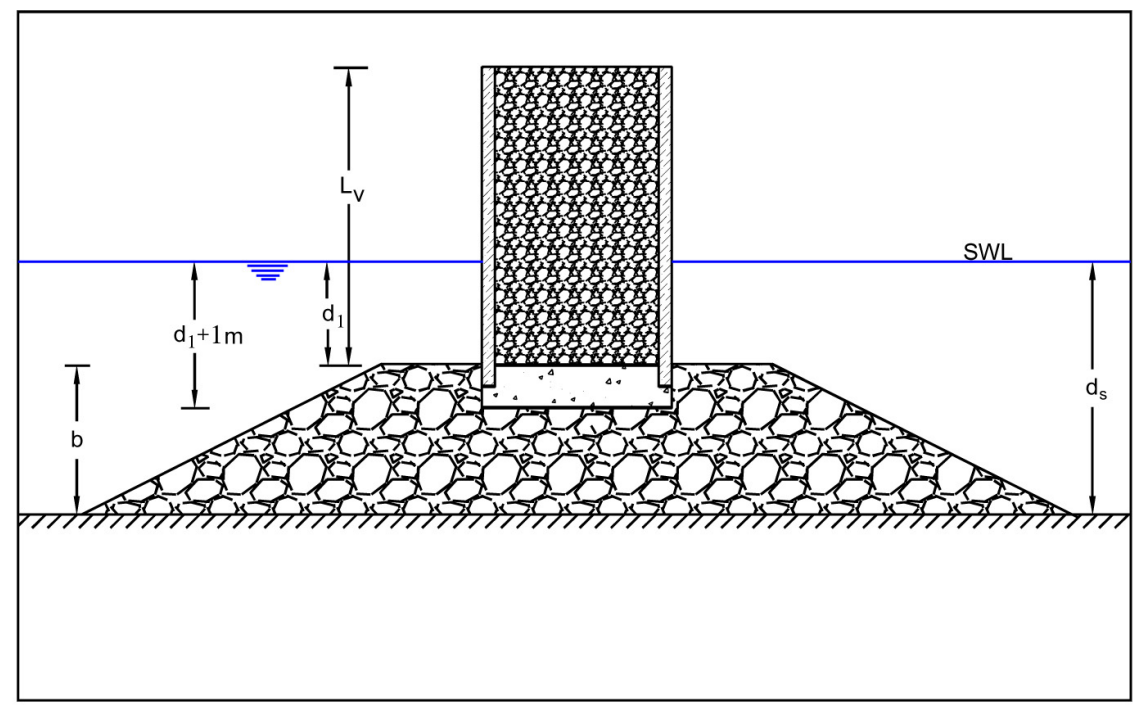

Figure 2: Composite breakwater cross-section.

The wave action is one of the systems involving gravity and inertia forces, a ratio of inertia to gravity forces is known as the Froude number $\left(\mathrm{F}_{\mathrm{r}}{ }^{2}=\mathrm{v}^{2} / \mathrm{gL}\right.$, where $\mathrm{v}$ is a velocity, $\mathrm{g}$ the acceleration due to gravity and $\mathrm{L}$ is a characteristic length). For situations where inertia and gravity forces predominate, dynamic similarity is achieved when geometric similarity is ensured and Froude's number is the same in model and prototype. This law requires that the Froude number $\left(F_{r}\right)$ be the same in model and prototype. The length scale, denoted by $n_{L}$ is defined as the ratio of length in prototype to length in the model. Following the Froude law the other relevant scale factors become:

$$
\begin{array}{lcc}
\text { Wave height and length }(\mathrm{m}) & \mathrm{n}_{\mathrm{H}}=\mathrm{n}_{\mathrm{L}} \\
\text { Wave period and time } & (\mathrm{s}) & \mathrm{n}_{\mathrm{T}}=\left(\mathrm{n}_{\mathrm{L}}\right)^{1 / 2} \\
\text { Wave velocity }(\mathrm{m} / \mathrm{s}) & \mathrm{n}_{\mathrm{V}}=\left(\mathrm{n}_{\mathrm{L}}\right)^{1 / 2} \\
\text { Wave force }(\mathrm{N}) & \mathrm{n}_{\mathrm{F}}=1.025\left(\mathrm{n}_{\mathrm{L}}\right)^{3}
\end{array}
$$

All the above scale factors are based on the condition that both the model and prototype are acted upon by the earth's gravitational field $\left(\mathrm{n}_{\mathrm{g}}=1\right)$. 


\subsection{Model design}

\subsubsection{Pipe model material}

Pipe model material was scaled for similarity of the stability number $H_{i} / \Delta D_{n}$, where the submerged density is defined as $\Delta=\left(\rho_{\mathrm{a}}-\rho_{\mathrm{w}}\right) / \rho_{\mathrm{w}} ; \rho_{\mathrm{a}}$ is the mass density of the pipe material and $\rho_{\mathrm{w}}$ is the mass density of water. $D_{n}$ is the nominal diameter of the armor material defined as $D_{n}=\left(M / \rho_{a}\right)^{(1 / 3)}$ with $M$ being the mass of the armor unit. Similarity means that the stability parameter should be the same in model and prototype and in this way the effects of having different mass densities of water and armor units in the model, compared to the prototype situation, is accounted for. In prototype salt water is present with a mass density of about $1025 \mathrm{~kg} / \mathrm{m}^{3}$ whereas fresh water with a density of $1000 \mathrm{~kg} / \mathrm{m}^{3}$ was used in the model. The relationship between model and prototype armor is described by the relation:

$$
\mathrm{M}_{\mathrm{m}}=\left(\mathrm{n}_{\mathrm{L}}\right)^{-3}\left(\rho_{\mathrm{m}} / \rho_{\mathrm{p}}\right)\left(\Delta_{\mathrm{p}} / \Delta_{\mathrm{m}}\right)^{3} \mathrm{M}_{\mathrm{p}}
$$

The subscripts $m$ and $p$ refer to model and prototype conditions, respectively. The linear scaling of 1 to 50 was chosen first to satisfy the available flume dimensions, in other words the model units must be fully confined within the flume, and then checked if this scaling satisfies the material similitude or not.

To ensure that the stability of the model units resembles that of the prototype units, the stability parameter must be the same in the model and in the prototype.

$$
\text { Nominal diameter }=\mathrm{D}_{\mathrm{n}}=\left(\frac{\text { Mass }}{\text { Density }}\right)
$$

$$
\text { Stability Number }=\left(\mathrm{H}_{\mathrm{i}} / \Delta \mathrm{D}_{\mathrm{n}}\right)
$$

$\mathrm{H}_{\mathrm{i}}$ is the incident wave height.

\subsubsection{Rubble mound base model material}

To ensure the stability of the rubble base, worst case scenario is considered in the study according to the following equation (5):

$$
\mathrm{W}=\left(\mathrm{N}_{\mathrm{S}}\right)^{-3}\left(\mathrm{H}_{\mathrm{i}}\right)\left(\left(\mathrm{w}_{\mathrm{r}} / \mathrm{w}_{\mathrm{w}}\right)-1\right)^{3}
$$

$\mathrm{W}=$ mean weight of individual armor unit

$\mathrm{H}_{\mathrm{i}}=$ incident wave height $(4 \mathrm{~m})$

$\mathrm{N}_{\mathrm{S}}=$ design stability number for rubble foundation

$\mathrm{W}_{\mathrm{w}}=$ unit weight of water, for fresh water $\left(1000 \mathrm{~kg} / \mathrm{m}^{3}\right)$ and for sea water $\left(1025 \mathrm{~kg} / \mathrm{m}^{3}\right)$

$\mathrm{W}_{\mathrm{r}}=$ unit weight of armor unit $=2.6 \mathrm{ton} / \mathrm{m}^{3}$

$\mathrm{d}_{1}=$ the water depth above the rubble mound base

$\mathrm{d}_{\mathrm{S}}=$ the water depth at the breakwater 
In addition to the above parameters, the minimum ratio of the water depth above the rubble mound base to the water depth at the breakwater $\left(d_{1} / d_{S}\right)$ was taken as about 0.1 which resulted in a least value of $\left(\mathrm{N}_{\mathrm{S}}\right)^{3}$ of about 7.2. Table 1 summarizes parameters used for breakwater prototype and model.

Table 1: $\quad$ Summary of breakwater prototype and model parameters.

\begin{tabular}{|c|c|c|}
\hline Item & Prototype & Model \\
\hline PCCP units & Prestressed concrete & Aluminum \\
\hline Internal diameter $(\mathrm{mm})$ & 4000 & 79.20 \\
\hline External diameter (mm) & 4500 & 90 \\
\hline Length (mm) & 7500 & 150 \\
\hline Thickness (mm) & 250 & 5.41 \\
\hline Density $\left(\mathrm{kg} / \mathrm{m}^{3}\right)$ & 2916 & 2800 \\
\hline Mass (kg) & 73,000 & 0.600 \\
\hline PCCP base & Prestressed concrete & Aluminum \\
\hline Internal diameter $(\mathrm{mm})$ & 4000 & 79.18 \\
\hline Internal thickness $(\mathrm{mm})$ & 500 & 10 \\
\hline External diameter (mm) & 5500 & 90 \\
\hline External thickness (mm) & 500 & 1.41 \\
\hline Density $\left(\mathrm{kg} / \mathrm{m}^{3}\right)$ & 2500 & 2800 \\
\hline Mass $(\mathrm{kg})$ & 45,400 & 0.160 \\
\hline Fill Material (kg) & 127,925 & 0.988 \\
\hline Stability Number & $0.1853 \mathrm{H}_{\mathrm{i}}$ & $0.1853 \mathrm{H}_{\mathrm{i}}$ \\
\hline Total Mass (kg) & 246,325 & 1.748 \\
\hline Rubble Foundation Material & 6 to 7 tons stones & 40 to 50 grams gravel \\
\hline
\end{tabular}

\subsection{Laboratory testing facilities}

The model was constructed in the Scheldt flume located at Delft Laboratories, in the Netherlands, (Figure 3). The Scheldt wave flume is $56 \mathrm{~m}$ long, $0.99 \mathrm{~m}$ wide, $1.2 \mathrm{~m}$ deep, and capable of generating both regular (periodic) and irregular (random) waves. The wave generator is equipped with online active reflection compensation. This means that waves propagating towards the wave board are measured and that the wave board compensates for these reflected waves. In this 
way, these undesired waves do not re-reflect towards the model and do not disturb the measurements. Also wave board control for random second-order waves is operational to compensate for spurious waves.

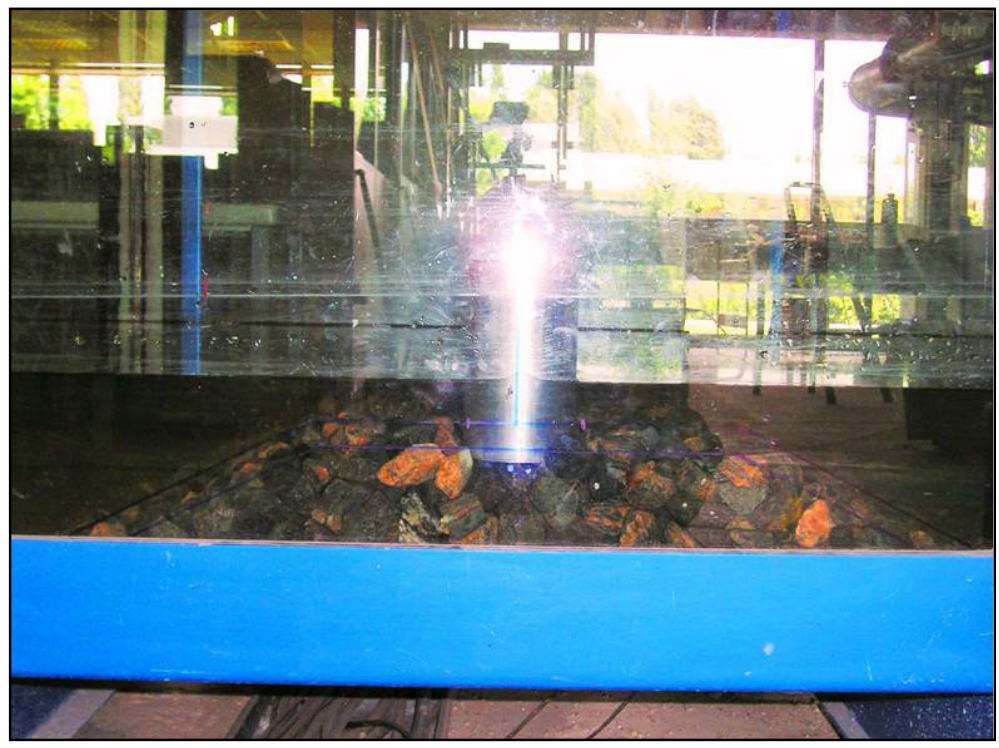

Figure 3: Composite breakwater model side view.

\section{Stability measurements and modes}

The model consists of eleven pipe units placed in vertical position on a gravel foundation. In order to assess the damage at different locations, the pipes were marked at the top ends by a straight colored line passing through the center of all the pipes.

According to test observations, stability modes were classified into three categories, in the form of rotation, displacement and overturning of the pipes, whereas any finite visible rotation, displacement, and overturning are considered as instability of the breakwater system in the model test.

The rotation occurs when the colored line between each two adjacent pipes becomes unstraight in reverse direction, while the displacement happens when the line shifted out of the original position. The overturning may occur partly or fully, the first one when the pipe still in position but inclined and the other when the pipe falls down in horizontal position.

\section{Testing program}

Five stability test series were performed, named SAA, SAB, SAC, SAD, and SAE. The test program for SAA series consists of 3 test runs while the other tests consisted of 7 test runs. The prototype wave data for the first four runs for each 
test are $\mathrm{d}_{\mathrm{S}}=8.25 \mathrm{~m}$ to $12.5 \mathrm{~m}, \mathrm{H}_{\mathrm{i}} / \mathrm{gT}^{2} \approx 0.001$ to 0.006 , and $\mathrm{d}_{\mathrm{S}} / \mathrm{gT}^{2} \approx 0.09$ to 0.15 . The foundation base height for the five test series SAA, SAB, SAC, SAD, and SAE are $10,9,8,10$, and $7 \mathrm{~m}$ respectively in the prototype scale.

\section{Test results and analysis}

For each run, the wave height results in each wave spectrum were illustrated as exceedance curves while the wave period results as relationship between the wave frequency against the wave energy per square meter. As a result of taking photos before, during and after each test run, the observed stability conditions for the breakwater after each test were documented (Figure 4).

The wave condition for all test runs was actually nonbreaking waves. A wave theoretical analysis also showed the same conditions. So stability analysis for the breakwater under the effect of nonbreaking wave forces were made for each test. Detailed results of model observed stability conditions are listed in Table 2. The results show wave and water depth conditions, calculated factor of safety (CFOS) for sliding and overturning, which are based on the calculated horizontal wave force and overturning moment acting on the PCCP respectively, and the observed stability condition. In general finite rotation was documented when the CFOS against sliding is lower than one even when CFOS against overturning is greater than one, making the sliding as the critical criterion for stability. Displacements of the PCCP unit were greatly visible when the pipe unit is placed directly on the rubble mound base (test series SAA) with overturning of the pipe units leading to complete failure during some tests.
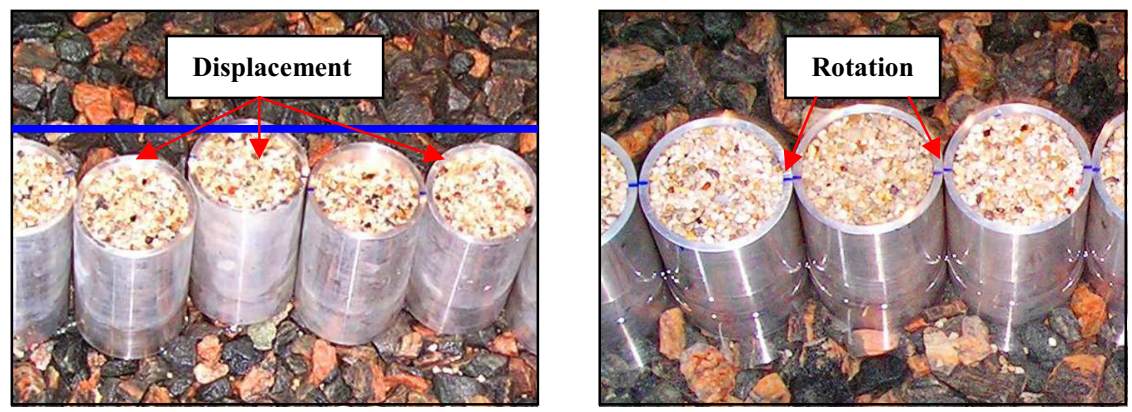

Figure 4: Displacement and rotation of pipes under a non-breaking wave.

\section{Implementation design criteria}

The results showed that throughout all the wave tests the wave conditions were nonbreaking, and the rubble foundation was stable under all tests. The stability analysis for the PCCP was concentrated upon the sliding and the overturning of individual pipe units. The testing showed that in case of the pipe fixed inside the rubble foundation it will rotate when the CFOS against sliding less is than one, even when CFOS against overturning is greater than one. 
Table 2: $\quad$ Calculated factors of safety.

\begin{tabular}{|c|c|c|c|c|c|}
\hline $\begin{array}{l}\text { Test } \\
\text { No. }\end{array}$ & $\mathrm{d} 1 / \mathrm{d}_{\mathrm{s}}$ & $\mathrm{H}_{\mathrm{i}} / \mathrm{gT}^{2}$ & $\begin{array}{l}\text { CFOS } \\
\text { (Sliding) }\end{array}$ & $\begin{array}{c}\text { CFOS } \\
\text { (Overturning) }\end{array}$ & Experimental observation \\
\hline SAB1 & 0.12 & 0.001940 & 8.51 & 19.90 & Stable \\
\hline SAB2 & 0.12 & 0.003885 & 2.39 & 4.94 & Stable \\
\hline SAB3 & 0.12 & 0.005204 & 1.20 & 2.09 & Stable \\
\hline SAB4 & 0.12 & 0.006019 & 0.85 & 1.21 & Unstable (Rotation) \\
\hline SAB5 & 0.22 & 0.004199 & 1.65 & 1.92 & Stable \\
\hline SAB6 & 0.22 & 0.005606 & 0.73 & 1.07 & Unstable (Rotation) \\
\hline SAB7 & 0.22 & 0.006452 & 0.57 & 0.60 & $\begin{array}{c}\text { Unstable (Rotation and } \\
\text { overturning) }\end{array}$ \\
\hline SAC1 & 0.14 & 0.001960 & 8.57 & 22.94 & Stable \\
\hline$\overline{\mathrm{SAC} 2}$ & 0.14 & 0.004005 & 2.18 & 2.58 & Stable \\
\hline SAC3 & 0.14 & 0.004935 & 1.30 & 1.65 & Stable \\
\hline SAC4 & 0.14 & 0.005661 & 0.82 & 1.15 & Unstable (Rotation) \\
\hline SAC5 & 0.24 & 0.003901 & 1.48 & 2.07 & Stable \\
\hline SAC6 & 0.24 & 0.005610 & 0.73 & 0.93 & Unstable (Rotation) \\
\hline SAC7 & 0.24 & 0.006377 & 0.53 & 0.77 & $\begin{array}{c}\text { Unstable (Rotation and } \\
\text { overturning) }\end{array}$ \\
\hline SAD1 & 0.11 & 0.001986 & 8.75 & 21.35 & Stable \\
\hline SAD2 & 0.11 & 0.003945 & 2.57 & 4.67 & Stable \\
\hline SAD3 & 0.11 & 0.005509 & 1.24 & 1.85 & Stable \\
\hline SAD4 & 0.11 & 0.006350 & 0.79 & 1.31 & Unstable (Rotation) \\
\hline SAD5 & 0.20 & 0.003873 & 1.66 & 2.42 & Stable \\
\hline SAD6 & 0.20 & 0.005483 & 0.87 & 1.06 & Unstable (Rotation) \\
\hline SAD7 & 0.20 & 0.006465 & 0.63 & 0.77 & $\begin{array}{c}\text { Unstable (Rotation and } \\
\text { overturning) }\end{array}$ \\
\hline SAE1 & 0.15 & 0.002123 & 6.36 & 18.90 & Stable \\
\hline SAE2 & 0.15 & 0.004155 & 1.41 & 2.58 & Stable \\
\hline SAE3 & 0.15 & 0.004398 & 1.26 & 1.92 & Stable \\
\hline SAE4 & 0.15 & 0.004839 & 1.03 & 1.44 & Stable \\
\hline SAE5 & 0.26 & 0.003877 & 1.36 & 2.12 & Stable \\
\hline SAE6 & 0.26 & 0.005340 & 0.69 & 1.17 & Unstable (Rotation) \\
\hline SAE7 & 0.26 & 0.005728 & 0.58 & 1.01 & Unstable (Rotation) \\
\hline SAA1 & 0.20 & 0.001072 & 0.75 & 0.93 & $\begin{array}{l}\text { Unstable (Displacement } \\
\text { and overturning) }\end{array}$ \\
\hline SAA2 & 0.20 & 0.004669 & 0.29 & 0.25 & $\begin{array}{l}\text { Unstable (Displacement } \\
\text { and overturning) }\end{array}$ \\
\hline SAA3 & 0.20 & 0.006193 & 0.23 & 0.19 & $\begin{array}{l}\text { Unstable (Displacement } \\
\text { and overturning) }\end{array}$ \\
\hline
\end{tabular}


However, pipes displace when placed directly on the rubble mound base leading to complete failure of these pipes under some tests.

The test runs showed that the maximum water depth $\left(\mathrm{d}_{\mathrm{S}}\right)$ under which the composite breakwater to be stable is $8.25 \mathrm{~m}$, while the maximum incident wave height is about $5 \mathrm{~m}$ with a peak wave period of about $9 \mathrm{~s}$. This stability condition however is accompanied with overtopping when the incident wave height exceeds $4 \mathrm{~m}$. The maximum allowable water depth above the rubble foundation under which the composite breakwater is stable is $2.5 \mathrm{~m}$. Table 3 summarizes the design criteria for PCCP composite breakwater based on computational and observed model results for nonbreaking waves.

Table 3: $\quad$ Design criteria for PCCP composite breakwater.

\begin{tabular}{|c|c|c|}
\hline No. & Parameter & Criteria \\
\hline 1.0 & PCCP & \\
\hline 1.1 & Minimum depth of immersed part in the foundation armor base & $0.5 \mathrm{~m}$ \\
\hline 1.2 & Minimum fill density & $1.455 \mathrm{t} / \mathrm{m}^{3}$ \\
\hline 2.0 & Concrete base & \\
\hline 2.1 & Inside part diameter & $4 \mathrm{~m}$ \\
\hline 2.2 & Inside part depth & $0.5 \mathrm{~m}$ \\
\hline 2.3 & Outside part diameter & $4.5 \mathrm{~m}$ \\
\hline 2.4 & Outside part depth & $0.5 \mathrm{~m}$ \\
\hline 3.0 & Rubble foundation base & \\
\hline 3.1 & Minimum foundation armor weight (density 2.6 tons $\left./ \mathrm{m}^{3}\right)$ & $6.5 \mathrm{tons}$ \\
\hline 3.2 & Minimum foundation toe length & $0.4 \mathrm{~d}$ \\
\hline 3.3 & Minimum foundation side slope (vertical to horizontal) & 1 to 2 \\
\hline 4.0 & Waves and water & $8.25 \mathrm{~m}$ \\
\hline 4.1 & Maximum incident wave height ( $\left.\mathrm{H}_{\mathrm{i}}\right)$ with minimum or no overtopping & $4 \mathrm{~m}$ \\
\hline 4.2 & Maximum peak wave period $\left(\mathrm{T}_{\mathrm{p}}\right)$ & $9 \mathrm{~s}$ \\
\hline 4.3 & Maximum water depth above foundation armor crest $\left(\mathrm{d}_{1}\right)$ & $2.5 \mathrm{~m}$ \\
\hline 4.4 & Maximum water depth $\left(\mathrm{d}_{\mathrm{s}}\right)$ & \\
\hline
\end{tabular}

\section{Conclusions}

The conceptual use of the prestressed concrete cylinder pipes, made by the Great Man-Made River Project, as composite breakwaters was investigated. To further 
confirm computed stability of this use of the PCCP as composite breakwaters, a two-dimensional physical model study was performed.

All test runs showed that, in parallel with the wave analysis, the wave conditions were nonbreaking. The rubble foundation was stable under all tests. The testing showed that in case of the pipe fixed inside the rubble foundation it will rotate when the factor of safety against sliding is less than one while in some cases the factor of safety against overturning is greater than one, similarly the pipe overturns when the factor of safety against overturning is less than one while in all cases the factor of safety against sliding is less than one. In case of placing the pipe directly on the rubble foundation, the pipe displaces under a factor of safety against sliding of less than one and complete pipe failure could occur.

Based on the experimental observed results and computed wave forces on the PCCP composite breakwater, stability criteria were deduced. Prototype scale dimensions including maximum water depth and wave height are set for the implementation of the 4-m diameter PCCP as composite breakwaters.

\section{References}

[1] Ghazali, A., Barony, S., \& Mohamed, R. "Use of Prestressed Concrete Pipes as Breakwaters for Small Ports in Libya" 4th International Conference on Coasts, Ports, and Marine Structures ICOPMAS "2000" Iran.

[2] Robert, M. S., "Basic Coastal Engineering”, John Wiley and Sons, New York, 1978.

[3] Rundgren, L., "Water Wave Forces, "Bulletin No. 54, Royal Institute of Technology, Division of Hydraulics, Stockholm, Sweden, 1958.

[4] Sainflou, M., " Treatise on Vertical Breakwaters, "Annals des Ponts et Chaussees, Paris, 1928. (Translated by W.J. Yardoff, U.S. Army Corps of Engineers.).

[5] U.S. Army Corps of Engineers, "Coastal Engineering Manual", Washington DC. 2002. 